\title{
Two new endophytic Colletotrichum species from Nothapodytes pittosporoides in China
}

\author{
Sixuan Zhou ${ }^{1,2}$, Lijun Qiao', Ruvishika S. Jayawardena ${ }^{3}$, Kevin D. Hyde ${ }^{3}$, \\ Xiaoya Ma',3, Tingchi Wen', Jichuan Kang'
}

I Engineering Research Center of the Utilization for Characteristic Bio-Pharmaceutical Resources in Southwest, Ministry of Education/College of Life Sciences, Guizhou University, Guiyang, Guizhou Province 550025, China 2 Institute of Animal Husbandry and Veterinary, Guizhou Academy of Agricultural Sciences, Guiyang, Guizhou province 550006, China 3 Center of Excellence in Fungal Research, Mae Fah Luang University, Chiang Rai 57100, Thailand

Corresponding author: Jichuan Kang (jckang@gzu.edu.cn)

Academic editor: T. Lumbsch | Received 25 November 2018 | Accepted 20 February 2019 | Published 11 March 2019

Citation: Zhou S, Qiao L, Jayawardena RS, Hyde KD, MaX, Wen T, Kang J (2019) Two new endophytic Colletotrichum species from Nothapodytes pittosporoides in China. MycoKeys 49: 1-14. https://doi.org/10.3897/mycokeys.49.31904

\begin{abstract}
Two new endophytic species, Colletotrichum jishouense sp. nov. and. C. tongrenense sp. nov. were isolated from Nothapodytes pittosporoides in Guizhou and Hunan provinces, China. Detailed descriptions and illustrations of these new taxa are provided and morphological comparisons with similar taxa are explored. Phylogenetic analysis with combined sequence data (ITS, GAPDH, ACT and TUB2) demonstrated that both species formed distinct clades in this genus. This is the first record of Colletotrichum species from $N$. pittosporoides in China.
\end{abstract}

\section{Keywords}

Ascomycota, Multi-loci, Phylogeny, Morphology, Taxonomy

\section{Introduction}

Nothapodytes pittosporoides (Oliv.) Sleum (Icacinacceae) has been used as Traditional Chinese Medicine (TCM) and is mainly distributed in southern China (Fang 1981). It is quickly gaining attention as the characteristic compounds of camptothecin and its derivatives (CIDs) in N. pittosporoides (Dong et al. 2015) are used as anti-cancer drugs in the world market (Demain and Vaishnav 2011). It is recognised that endophytes reside in the internal tissues of living plants and potentially have the capability to produce the same functional compounds as their hosts (Stierle et al. 1993, 1995; Kusari et al.

Copyright Sixuan Zhou et al. This is an open access article distributed under the terms of the Creative Commons Attribution License (CC BY 4.0), which permits unrestricted use, distribution, and reproduction in any medium, provided the original author and source are credited. 
2008; Bhalkar et al. 2016; Uzma et al. 2018). The endophytic fungi in $N$. pittosporoides were therefore studied for their secondary metabolites with pharmaceutical potential.

Endophytic fungi were isolated from different parts of Nothapodytes pittosporoides (Zhou et al. 2017; Qiao et al. 2018) collected from different sites. A high diversity of fungi were found, of which several species of Colletotrichum were isolated and identified.

Colletotrichum species are globally distributed and occur in various plants as endophytes (Tibpromma et al. 2018). Colletotrichum is the sole genus in the family Glomerellaceae (Glomerellales, Sordariomycetes, Wijayawardene et al. 2018) and was introduced by Corda (1831) with the type species C. lineola (Jayawardena et al. 2016, 2017, Wijayawardene et al. 2017). Recently, several studies have analysed this genus and these are summarised in Hyde et al. (2014), who accepted 163 names. Since this review, about 30 more species have been introduced (Baroncelli et al. 2017; Douanlameli et al. 2017; Jayawardena et al. 2017; Silva et al. 2018).

In this study, we introduce two novel species, $C$. jishouense sp. nov. and $C$. tongrenense sp. nov. isolated as endophytes from $N$. pittosporoides. These species are based on both morphological features and molecular sequence data evidence.

\section{Material and methods}

\section{Sample collection}

Fresh healthy plant samples (leaves, stems and roots) of Nothapodytes pittosporoides were collected in Tongren City, Guizhou Province and Jishou City, Hunan Province, China. Materials were kept in zip-lock bags on ice. Fungal isolation was carried out within 24 hours of collection.

\section{Isolation and cultivation of fungal endophytes}

Each part of the plant was surface sterilised to eliminate epiphytic microorganisms. The samples were washed thoroughly in running tap water, followed by immersion in $70 \%$ (v/v) ethanol for 3 min to sterilise the surfaces, then rinsed with sterilised distilled water for $1 \mathrm{~min}$. Samples were dried on sterilised filter paper and then placed in 3\% hydrogen peroxide for $7 \mathrm{~min}$, washed in sterilised distilled water and dried on a sterilised filter paper again. Each plant tissue was then cut into small cubes $(0.5 \times 0.5 \mathrm{~cm})$ using a sterilised blade. The cubes were placed on potato dextrose agar (PDA) medium in Petri dishes containing with antibiotic $(100 \mathrm{mg} / \mathrm{l}$ chloramphenicol) and incubated at $25^{\circ} \mathrm{C}$ until fungal growth emerged from the plant segments. The endophytic fungi were isolated and sub-cultured on fresh PDA plates at $25^{\circ} \mathrm{C}$ in darkness. Fungal isolates were stored on PDA and covered with sterilised water at $4{ }^{\circ} \mathrm{C}$.

The type specimens are deposited in Guizhou Agricultural College (GACP), Guiyang, China. Ex-type living cultures are deposited at Guizhou Medical University Culture Collection (GMBC). Mycobank numbers are provided. 


\section{DNA extraction, PCR amplification, and sequencing}

Genomic DNA was extracted from fresh fungal mycelia using the BIOMIGA Fungus Genomic DNA Extraction Kit (GD2416, Biomiga, USA), following the manufacturer's instructions. DNA samples were stored at $-20{ }^{\circ} \mathrm{C}$ until used for polymerase chain reaction (PCR). Four loci, rDNA regions of internal transcribed spacers (ITS), partial $\beta$-tubulin (TUB2), actin (ACT) and glyceraldehyde-3-phosphate dehydrogenase (GAPDH) genes were amplified by PCR with primers ITS1 (Gardes and Bruns 1993) + ITS4 (White et al. 1990), Bt-2a + Bt-2b (Glass and Donaldson 1995), ACT-512F + ACT-783R (Carbone and Kohn 1999) and GDF1 + GDR1 (Guerber et al. 2003), respectively. The components of a $50 \mu \mathrm{l}$ volume PCR mixture were used as follows: $2.0 \mu \mathrm{l}$ of DNA template, $1 \mu \mathrm{l}$ of each forward and reverse primer, $25 \mu \mathrm{l}$ of $2 \times$ Easy Taq PCR Super Mix (mixture of Easy Taq TM DNA Polymerase, dNTPs and optimised buffer, Beijing Trans Gen Biotech Co., Chaoyang District, Beijing, China) and $19 \mu \mathrm{l}$ sterilised water. PCR thermal cycle programmes for ITS and ACT gene amplification were provided as: initial denaturation at $95^{\circ} \mathrm{C}$ for $3 \mathrm{~min}$, followed by 35 cycles of denaturation at $95^{\circ} \mathrm{C}$ for $30 \mathrm{~s}$, annealing at $52^{\circ} \mathrm{C}$ for $50 \mathrm{~s}$, elongation at $72^{\circ} \mathrm{C}$ for $45 \mathrm{~s}$ and final extension at $72{ }^{\circ} \mathrm{C}$ for $10 \mathrm{~min}$. The PCR thermal cycle programme for GAPDH gene amplification was provided as: initial denaturation at $95^{\circ} \mathrm{C}$ for $3 \mathrm{~min}$, followed by 35 cycles of denaturation at $94^{\circ} \mathrm{C}$ for $30 \mathrm{~s}$, annealing at $60^{\circ} \mathrm{C}$ for $30 \mathrm{~s}$, elongation at $72^{\circ} \mathrm{C}$ for $45 \mathrm{~s}$ and final extension at $72{ }^{\circ} \mathrm{C}$ for $10 \mathrm{~min}$. The PCR thermal cycle programme for TUB2 gene amplification was provided as: initial denaturation $95^{\circ} \mathrm{C}$ for $3 \mathrm{~min}$, followed by 35 cycles of denaturation at $94^{\circ} \mathrm{C}$ for $30 \mathrm{~s}$, annealing at $55^{\circ} \mathrm{C}$ for $45 \mathrm{~s}$, elongation at $72{ }^{\circ} \mathrm{C}$ for $45 \mathrm{~s}$ and final extension at $72{ }^{\circ} \mathrm{C}$ for $10 \mathrm{~min}$. The quality of PCR products were checked with $1.5 \%$ agarose gel electrophoresis stained with ethidium bromide. PCR products were sent for sequencing to Sangon Co., Shanghai, China.

\section{Sequence alignment and phylogenetic analyses}

Sequence data of the four loci were blasted in the GenBank database and all top hits, including the corresponding type sequences, were retrieved (Table 1). Multiple sequence alignments for ITS, TUB2, ACT and GAPDH were constructed and carried out using the MAFFT v.7.110 online programme (http://mafft.cbrc.jp/alignment/server/, Katoh and Standley 2013) with the default settings. Four datasets of ITS, TUB2, ACT and GAPDH of Colletotrichum spp. were combined and manually adjusted using BioEdit v.7.0.5.3 (Hall 1999), then assembled using SequenceMatrix1.7.8 (Vaidya et al. 2011). The final alignments contained 1593 characters with gaps, ITS with 522 sites, TUB2 with 510 sites, ACT with 269 sites and GAPDH with 292 sites. Fifty-four taxa and 1593 sites were used for phylogenetic analyses. Gaps were treated as missing data in maximum likelihood (ML), Bayesian Inference (BI) and parsimony trees. The phylogeny website tools "ALTER" (Glez-Peña et al. 2010) were used to convert the alignment file from Fasta to PhyLip file for RAxML analysis and Nexus for MrBayes. All loci were tested based on single maximum likelihood (ML) trees and Bayesian Inference (BI) methods. 
Table I. Taxa used for phylogenetic analyses in the study.

\begin{tabular}{|c|c|c|c|c|c|}
\hline \multirow{2}{*}{ Species name } & \multirow{2}{*}{ Isolate No. ${ }^{b}$} & \multicolumn{4}{|c|}{ GenBank Accession No. } \\
\hline & & ITS & GAPDH & ACT & TUB \\
\hline Colletotrichum agaves & AR3920 & DQ286221 & $-^{\mathrm{a}}$ & - & - \\
\hline C. anthrisci & CBS $125334^{*}$ & GU227845 & GU228237 & GU227943 & GU228139 \\
\hline C. aracearum & LC1041 & KX853167 & KX893586 & KX893578 & KX893582 \\
\hline C. arxii & CBS 132511 & KF687716 & KF687843 & KF687802 & KF687881 \\
\hline C. brevisporum & BCC $38876^{*}$ & JN050238 & JN050227 & JN050216 & JN050244 \\
\hline C. chlorophyte & IMI $103806^{*}$ & GU227894 & GU228286 & GU227992 & GU228188 \\
\hline C. citricola & SXC151* & KC293576 & KC293736 & KC293616 & KC293656 \\
\hline C. citri-maximae & AGMy0254* & KX943582 & KX943578 & KX943567 & KX943586 \\
\hline C. cliviae & CBS $125375^{*}$ & JX519223 & JX546611 & JX519240 & JX519249 \\
\hline C. coccodes & CBS 369.75 & HM171679 & HM171673 & HM171667 & JX546873 \\
\hline C. colombiense & CBS $129818^{*}$ & JQ005174 & JQ005261 & JQ005522 & JQ005608 \\
\hline C. conoides & CAUG17* & KP890168 & KP890162 & KP890144 & KP890174 \\
\hline C. constrictum & CBS $128504^{*}$ & JQ005238 & JQ005325 & JQ005586 & JQ005672 \\
\hline C. cordylinicola & ICMP18579* & JX010226 & JX009975 & HM470235 & JX010440 \\
\hline C. dematium & CBS $125.25^{*}$ & GU227819 & GU228211 & GU227917 & GU228113 \\
\hline C. dracaenophilum & CBS 118199 & JX519222 & JX546707 & JX519238 & JX519247 \\
\hline C. euphorbiae & СРС 21823 & KF777146 & KF777131 & KF777125 & KF777247 \\
\hline C. excelsum-altitudum & CGMCC $3.15130^{*}$ & HM751815 & KC843502 & KC843548 & JX625211 \\
\hline C. fructi & CBS $346.37^{*}$ & GU227844 & GU228236 & GU227942 & GU228138 \\
\hline C. fuscum & CBS $133701^{*}$ & KM105174 & KM105524 & KM105384 & KM105454 \\
\hline C. fusiforme & MFLU 13-0291* & KT290266 & KT290255 & KT290251 & KT290256 \\
\hline C. gigasporum & CBS 133266 & KF687715 & KF687822 & - & KF687866 \\
\hline C. godetiae & CBS $133.44^{*}$ & JQ948402 & JQ948733 & JQ949723 & JQ950053 \\
\hline C. grevilleae & CBS $132879^{*}$ & KC297078 & KC297010 & KC296941 & KC297102 \\
\hline C. hymenocallidicola & MFLUCC 12-0531* & KT290264 & KT290263 & - & - \\
\hline C. jishouense & GZU_HJ2_G2 & MH482931 & MH681657 & MH708134 & MH727472 \\
\hline C. jishouense & GZU_HJ2_G3 & MH482929 & MH681658 & MH708135 & MH727473 \\
\hline C. jishouense & GZU_HJ2_G4 & MH482932 & MH681659 & MH708136 & MH727474 \\
\hline C. jishouense & GZU_HJ3_J5 & MH482930 & MH492706 & MH708137 & - \\
\hline C. kahawae & C1266.1 & JX010231 & JX010012 & JX009452 & JX010444 \\
\hline C. ledebouriae & СРC $25671^{*}$ & KX228254 & - & KX228357 & - \\
\hline C. liaoningense & CAUOS2* & KP890104 & KP890135 & KP890097 & KP890111 \\
\hline C. lindemuthianum & CBS $144.31^{*}$ & JQ005779 & JX546712 & JQ005842 & JQ005863 \\
\hline C. magnisporum & CBS 398.84 & KF687718 & KF687842 & KF687803 & KF687882 \\
\hline C. malvarum & CBS $521.97^{*}$ & KF178480 & KF178504 & KF178577 & KF178601 \\
\hline C. neosansevieriae & СРC $25127^{*}$ & KR476747 & KR476791 & KR476790 & KR476797 \\
\hline C. nymphaeae & CBS 515.78 & JQ948197 & JQ948527 & JQ949518 & JQ949848 \\
\hline C. orchidophilum & CBS $632.80^{*}$ & JQ948151 & JQ948481 & JQ949472 & JQ949802 \\
\hline C. pisicola & CBS 724.97* & KM105172 & KM105522 & KM105382 & KM105452 \\
\hline C. pseudoacutatum & CBS $436.77^{*}$ & JQ948480 & JQ948811 & JQ949801 & JQ950131 \\
\hline C. pseudomajus & CBS 571.88 & KF687722 & KF687826 & KF687801 & KF687883 \\
\hline C. radices & CBS 529.93 & KF687719 & KF687825 & KF687785 & KF687869 \\
\hline C. rhombiforme & CBS $129953^{*}$ & JQ948457 & JQ948788 & JQ949778 & JQ950108 \\
\hline C. sansevieriae & MAFF $239721^{*}$ & NR_152313 & - & - & - \\
\hline C. spinosum & CBS $515.97^{*}$ & KF178474 & KF178498 & KF178571 & KF178595 \\
\hline C. tanaceti & CBS $132693^{*}$ & JX218228 & JX218243 & JX218238 & JX218233 \\
\hline C. trichellum & CBS 217.64* & GU227812 & GU228204 & GU227910 & GU228106 \\
\hline C. tongrenense & GZU_TRJ1-37 & MH482933 & MH705332 & MH717074 & MH729805 \\
\hline C. tropicicola & L58 & JN050240 & JN050229 & JN050218 & JN050246 \\
\hline C. truncatum & CBS 151.35 & GU227862 & GU228254 & GU227960 & GU228156 \\
\hline C. vietnamense & CBS 125478 & KF687721 & KF687832 & KF687792 & KF687877 \\
\hline C. yunnanense & CBS $132135^{*}$ & JX546804 & JX546706 & - & JX519248 \\
\hline Monilochaetes infuscans & CBS 869.96 & JQ005780 & JX546612 & JQ005843 & JQ005864 \\
\hline
\end{tabular}

Notes: New strains are in bold. * ex-type strains. ${ }^{\mathbf{a}}$ No data in GenBank. ${ }^{\mathbf{b}}$ BCC: BIOTEC Culture Collection, National Center for Genetic Engineering and Biotechnology (BIOTEC), Khlong Luang, Pathumthani, Thailand; CBS: Culture collection of the Centraalbureau voor Schimmelcultures, Fungal Biodiversity Centre, Utrecht, The Netherlands; CGMCC: China General Microbiological Culture Collection; CPC: Working collection of Pedro W. Crous, housed at CBS; IMI: Culture collection of CABI Europe UK Centre, Egham, UK; LC: Working collection of Lei Cai, housed at CAS, China; MAFF: MAFF GenBank Project, Ministry of Agriculture, Forestry and Fisheries, Tsukuba, Japan; MFLUCC: Mae Fah Luang University Culture Collection, Chiang Rai, Thailand; MFLU: Herbarium of Mae Fah Luang University, Chiang Rai, Thailand; ICMP: International Collection of Microorganisms from Plants, Auckland, New Zealand. 


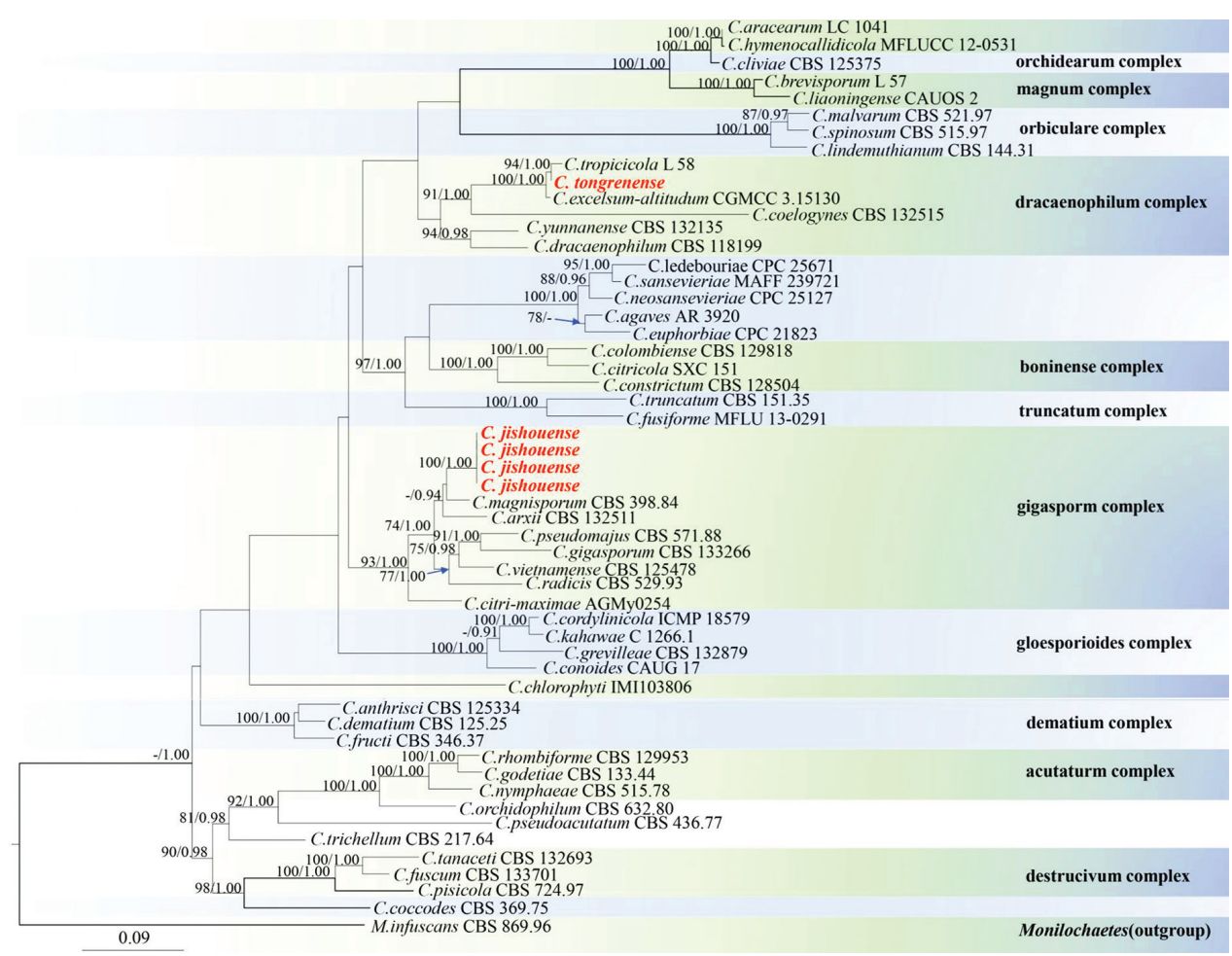

Figure I. Phylogram generated from Maximum Likelihood (RAxML) analysis based on combined ITS, ACT, TUB2 and GAPDH DNA sequence data of Colletotrichum. Bayesian Posterior Probabilities (BSPP) greater than 0.90 and Maximum Likelihood Bootstrap Support values (MLBS) greater than $70 \%$ are shown above branches. New isolates are in red. The tree is rooted with Monilochaetes infuscans CBS 869.96.

Maximum Likelihood (ML) analysis was performed on the website of CIPRES Science Gateway v.3.3 (http://www.phylo.org/portal2/, Miller et al. 2010) using RAxMLHPC Blackbox version 8.2.10. All free model parameters were estimated by RAxML and ML estimate of 25 per site rate categories. Final ML searches were conducted using the GTRGAMMA model. Bootstrap Support values (BS) equal to or greater than $60 \%$ are given above each node (Fig. 1).

For Bayesian Inference (BI), a Markov Chain Monte Carlo (MCMC) algorithm was used to generate phylogenetic trees with Bayesian probabilities using MrBayes 3.2.6 (Ronquist et al. 2012) for the combined sequence datasets. MrModeltest v.2.3 (Nylander 2004) was used to carry out the statistical selection of the best-fit model of nucleotide substitution. GTR $+G$ model was selected for ITS, a $G T R+I+G$ model for TUB2, a HKY+I+G model for ACT and GAPDH were incorporated into the analysis. Models of nucleotide substitution for each gene determined by MrModeltest v. 2.3 were included for each set of gene sequence data. Two runs were executed simultaneously for 1,000,000 generations and sampled every 100 generations. Of the trees, $25 \%$ were discarded as burn-in and the remaining trees were used to calculate the posterior probabilities. Convergence was assumed when the standard deviation of split 
sequences was less than 0.01. Phylogenetic trees were visualised using FigTree v1.4.0 (http://tree.bio.ed.ac.uk/software/figtree/, Rambaut 2012). The final alignment was deposited in Treebase (http://www.treebase.org, submission number 23622).

\section{Morphological analysis}

Isolates were grown on PDA, water agar (WA) with bamboo and corn malt agar medium (CMA) for examination of morphological characters. Colonies were examined after 7,14 and $21 \mathrm{~d}$ at $25^{\circ} \mathrm{C}$ in darkness. The morphological characters of mycelia, conidiophores, conidiogenous cells and conidia were observed and photographed using a Nikon NI-SS microscope and processed with Adobe Photoshop CS3 Extended version 10.0 software (Adobe Systems, USA).

\section{Results}

\section{Sample collection and isolation}

Four hundred and forty endophytic fungi were isolated from different parts of Nothapodytes pittosporoides in Jishou, Hunan Province and Tongren, Guizhou Province, belonging to twenty-four genera based on ITS sequences analysis. Colletotrichum was a common genus amongst the isolates. Herein, five endophytic taxa were isolated and identified as Colletotrichum of which GZU_HJ2_G2, GZU_HJ2_G3 and GZU_ HJ2_G4 were isolated from roots and GZU_HJ3_J5 from stems of $N$. pittosporoides in Jishou, Hunan Province. GZU_TRJ1-37 was isolated from stems of $N$. pittosporoides in Tongren, Guizhou Province.

\section{Phylogenetic analyses}

Phylogenetic analysis of four loci (ITS, GAPDH, ACT and TUB2) sequence datasets included 54 taxa, 1,593 positions including gaps (ITS: 1-522, TUB2: 523-1032, ACT: 1033-1301, GAPDH: 1302-1593) and Monilochaetes infuscans (CBS 869.96) was selected as the outgroup taxon. The $50 \%$ majority rule consensus Bayesian phylogram presented in Fig. 1 and the topology is recovered with the RAxML tree. Values of the Bayesian PP $\geq 0.70$ from MCMC analyses and bootstrap support values of $\mathrm{RAxML} \geq 90 \%$ are given on the branches.

Representatives of complexes and species in Colletotrichum (Noireung et al. 2012; Tao et al. 2013; Liu et al. 2014; Jayawardena et al. 2016; Douanla-meli et al. 2017) are included in the phylogenetic analyses (Fig. 1). Four isolates, GZU_HJ2_G2, GZU_ HJ2_G3, GZU_HJ2_G4 and GZU_HJ3_J5, were identified as distinct new species and are described as Colletotrichum jishouense sp. nov., and as C. tongrenense sp. nov., based on their morphology and molecular phylogeny. 


\section{Taxonomy}

Colletotrichum jishouense SX. Zhou, JC. Kang \& K.D. Hyde, sp. nov. MycoBank number: MB828723

Fig. 2

Etymology. 'Jishouense' referring to Jishou City, site of collection of type species.

Description. Endophytic fungus in root of Nothapodytes pittosporoides. Sexual morph: Undetermined. Asexual morph: Vegetative hyphae 0.5-1.2 $\mu \mathrm{m}$ diam. $(\mathrm{n}=10)$, hyaline, smooth-walled, septate, branched. Chlamydospores not observed. Conidiophores formed on a basal cushion, hyaline to pale brown, clavate or cylindrical, septate and irregularly branched. Conidiogenous cells $4-11 \times 2-3 \mu \mathrm{m}(\bar{x}=6.7 \pm 3.0 \times 2.6 \pm 0.4 \mu \mathrm{m}$, $\mathrm{n}=20$ ), $\mathrm{L} / \mathrm{W}$ ratio $=2.5$, hyaline, smooth-walled, clavate to mostly ampulliform or cylindrical. Conidia hyaline, smooth-walled, aseptate, straight, cylindrical, some clavate, the apex and base rounded, $5-14 \times 3-5 \mu \mathrm{m}(\bar{x}=10.8 \pm 1.8 \times 3.7 \pm 0.5 \mu \mathrm{m}, \mathrm{n}=40)$, $\mathrm{L} / \mathrm{W}$ ratio= 2.9. Appressoria not observed.

Culture characteristics. Colonies on PDA, reaching 55-60 mm diam. in 14 days at $25^{\circ} \mathrm{C}$ in darkness, circular, mycelium superficial and partially immersed, more or less planar, brown in the medium but covered with abundant, pale and lanose to cottony aerial mycelium, reverse greenish pale brown, margin entire and irregular.

Material examined. CHINA, Hunan Province, Jishou City $\left(28^{\circ} 55^{\prime} 24^{\prime \prime N}\right.$, $109^{\circ} 10^{\prime} 24$ "E), isolated from healthy roots of Nothapodytes pittosporoides, 27 May 2016, S.X. Zhou (Holotype GACP GZU_HJ2_G3 dried culture), ex-type living culture, GMBC0209, living culture, GZU_HJ2_G2, living culture, GZU_HJ2_G4.

China, Hunan Province, Jishou City $\left(28^{\circ} 55^{\prime} 24^{\prime \prime N}, 109^{\circ} 10^{\prime} 24 " E\right)$, isolated from healthy stem of Nothapodytes pittosporoides, 27 May 2016, S.X. Zhou, living culture, GZU_HJ3_J5.

Notes. Colletotrichum jishouense belongs in the gigasporum species complex. $C$. jishouense has shorter and narrower conidiogenous cells and conidia than all the related species in the C. gigasporum complex (Liu et al. 2014). Phylogenetically, our four new isolates clustered together with C. magnisporum (CBS 398.84). The pairwise dissimilarities of DNA sequences between C. jishouense and C. magnisporum were $2 \mathrm{bp}, 20 \mathrm{bp}$, 5 bp and 9 bp in ITS, TUB2, ACT and GAPDH, respectively. They are phylogenetically distinct species and, therefore, $C$. jishouense sp. nov. is introduced.

\section{Colletotrichum tongrenense S.X. Zhou, J.C. Kang \& K.D. Hyde, sp. nov.} MycoBank number: MB828725

Fig. 3

Etymology. 'tongrenense' referring Tongren City, site of collection of type species.

Description. Endophytic in leaves and stems of Nothapodytes pittosporoides. Sexual morph: Undetermined. Asexual morph: On WA, vegetative hyphae 1.4-6 $\mu \mathrm{m}$ diam. $(\mathrm{n}=10)$, smooth-walled, septate, branched, hyaline. Chlamydospores not 

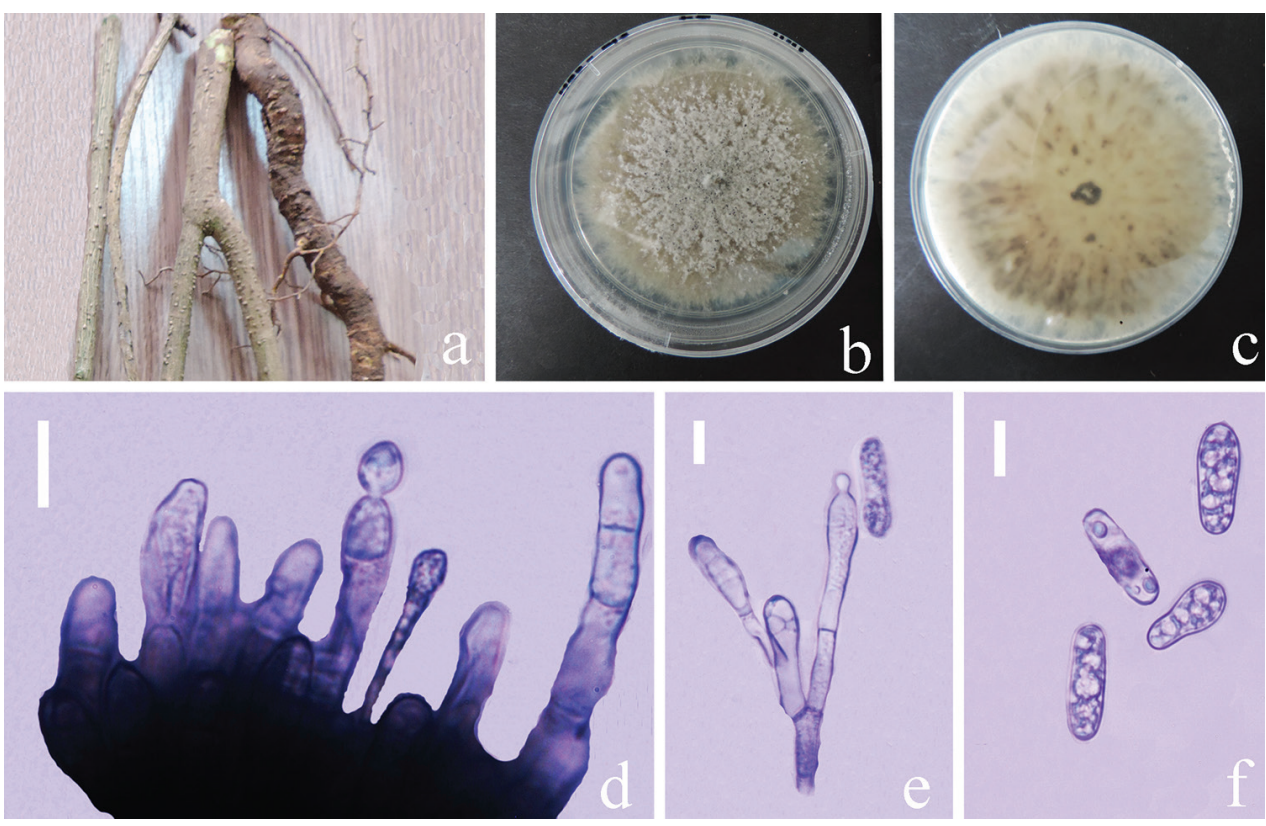

Figure 2. Colletotrichum jishouense (GACP GZU_HJ2_G3, holotype) a stems and roots of Nothapodytes pittosporoides $\mathbf{b}, \mathbf{c}$ colonies on PDA $\mathbf{d}$ conidiophores in cotton blue $\mathbf{e}$ conidiophores with conidia in cotton blue $\mathbf{f}$ conidia in cotton blue. Scale bars: $10 \mu \mathrm{m}(\mathbf{d}), 5 \mu \mathrm{m}(\mathbf{e}, \mathbf{f})$.

observed. Setae unbranched, septate, tapering to rounded at apical end, pale brown to dark brown, smooth-walled, 45-90 $\mu \mathrm{m}$ long, 5.9-6.2 $\mu \mathrm{m}$ wide at widest part, 2.6-5.8 $\mu \mathrm{m}$ wide at bottom, 1.5-1.6 $\mu \mathrm{m}$ wide at apex. Conidiophores pale brown, septate, branched. Conidiogenous cells pale, hyaline, smooth-walled, erect, clavate or cylindrical, $2-11 \times 1-2 \mu \mathrm{m}(\bar{x}=6.3 \pm 4.4 \times 1.7 \pm 0.4 \mu \mathrm{m}, \mathrm{n}=20), \mathrm{L} / \mathrm{W}$ ratio= 3.7. Conidia hyaline, aseptate, smooth-walled, variable in size and shape, thickwalled, ellipsoidal to subglobose, the apex and base rounded, slightly constricted in the middle, $11-14 \times 5-7 \mu \mathrm{m}(\bar{x}=13.1 \pm 1.0 \times 5.5 \pm 0.6 \mu \mathrm{m}, \mathrm{n}=40), \mathrm{L} / \mathrm{W}$ ratio $=2.4$.

Culture characteristics. Cultures on WA at $25^{\circ} \mathrm{C}$ in darkness, reaching $15-18 \mathrm{~mm}$ diam. in 21 days, white to grey, asymmetrical surface, reverse dark grey to black.

Colonies on PDA at $25^{\circ} \mathrm{C}$ reaching $45-55 \mathrm{~mm}$ diam. in 12 days in darkness, circular, more or less planar, surface dark brown, covered with abundant, pale grey, lanose to cottony aerial mycelium, margin smooth, entire and pale white. Reverse dark grey, margin pale white.

Cultures on CMA, 10-15 mm diam. in 21 days, covered with dark brown aerial mycelium, sparse, reverse light brown, margin irregular.

Material examined. CHINA, Guizhou province, Tongren $\left(27^{\circ} 35^{\prime} 37^{\prime \prime} \mathrm{N}\right.$, $109^{\circ} 10^{\prime} 58^{\prime \prime} \mathrm{E}$, elevation $332.8 \mathrm{~m}$ ), isolated from healthy stems of Nothapodytes pittosporoides, 27 May 2016, S.X. Zhou and L.J. Qiao (Holotype GACP GZU-TRJ1-37 dried culture), ex-type living culture, GMBC0209. 

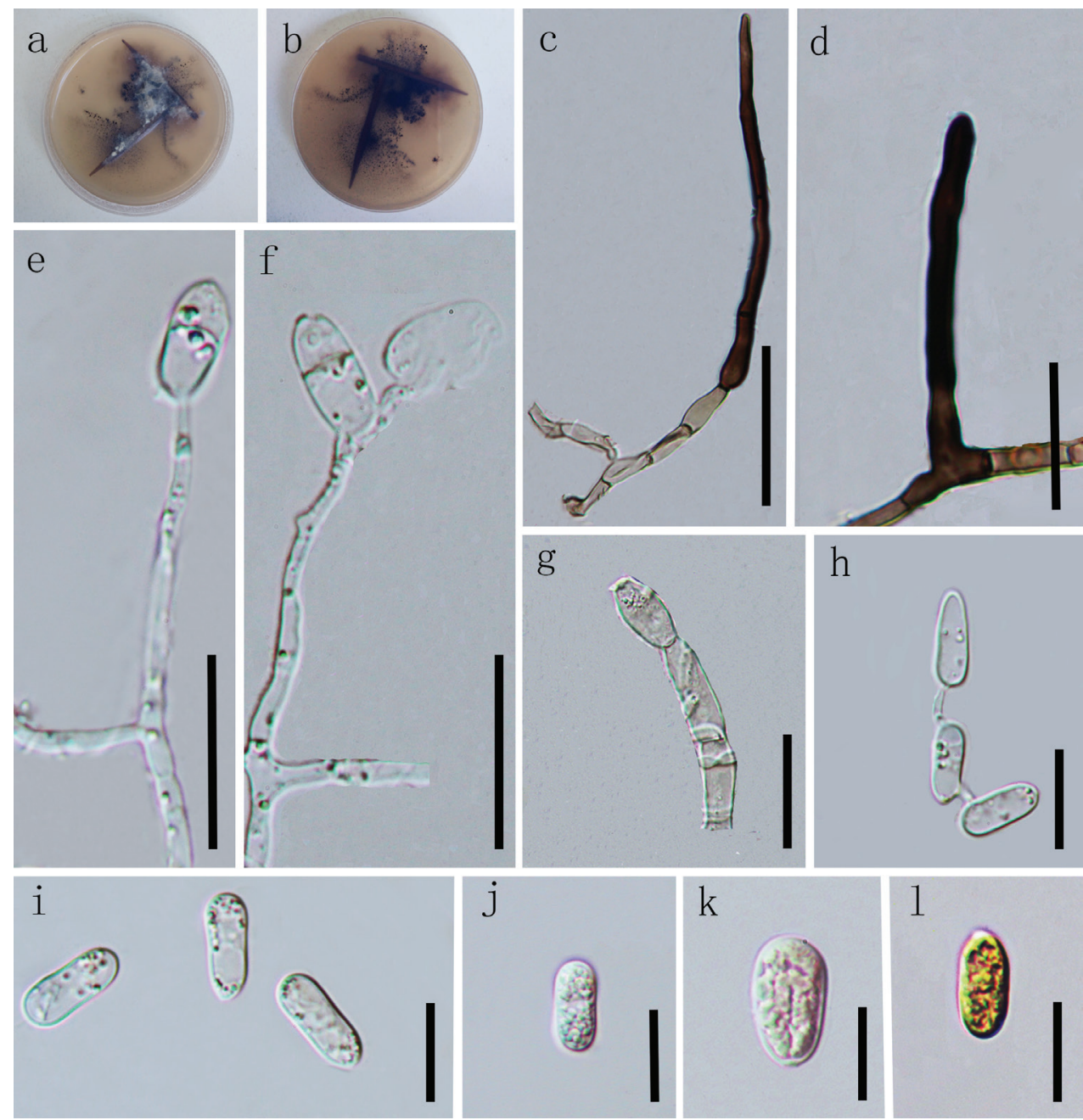

Figure 3. Colletotrichum tongrenense (GACP GZU_TRJ1-37, holotype) a, b colonies on WA c-g Conidiophores h-I Conidia. Scale bars: $40 \mu \mathrm{m}(\mathbf{c}), 20 \mu \mathrm{m}(\mathbf{d}, \mathbf{g}), 10 \mu \mathrm{m}(\mathbf{e}, \mathbf{f}), 10 \mu \mathrm{m}(\mathbf{h}-\mathbf{I})$.

Notes. Colletotrichum tongrenense belongs to the $C$. dracaenophilum species complex (Damm et al. 2019). Morphologically, C. tongrenense resembles C. tropicicola and C. excelsum-altitudum in conidia characters, but it can be distinguished from $C$. tropicicola in having setae and longer conidia (15-19 $\mu \mathrm{m} v s$ 11-14 $\mu \mathrm{m})$ (Noireung et al. 2012). $C$. tongrenense is distinguished from C. excelsum-altitudum (Tao et al. 2013) in having smaller conidiophores $(2-11 \times 1-2 \mu \mathrm{m}$ vs $8.5-25 \times 4-5 \mu \mathrm{m})$. Phylogenetically, the new isolate GZU_TRJ1-37 clusters together with C. tropicicola with good bootstrap support ( $94 \%$ MLBS, 1.00 PP) (Fig. 1) and the phylogenetic analysis supports it as a distinct species. There are 6, 4, 2 and 5 base pairs differences in ITS, TUB2, ACT and GAPDH gene regions, respectively, between the new isolate and the type strain of $C$. tropicicola, which confirms that they are separate species. Therefore, it is introduced as a novel species. 


\section{Discussion}

Colletotrichum appears to have a wide host range and a geographic distribution (Yang et al. 2009, Hyde et al. 2014, Jayawardena et al. 2016). This study reports on five endophytic Colletotrichum isolates which were isolated from Nothapodytes pittosporoides. Two new species were introduced, named $C$. jishouense and $C$. tongrenense, respectively, based on morphological characters and multilocus (ITS, TUB2, ACT and GAPDH) phylogenetic analyses. The C. gigasporum species complex is associated with various host plants as pathogens and endophytes and also isolated from air and stored grain, indicating that the members are not host-specific and apparently have different life styles (Than et al. 2008, Yang et al. 2009, Liu et al. 2014, Jayawardena et al. 2016). The C. dracaenophilum species complex contains a few apparently host-specific species and these species seem to be uncommon (Damm et al. 2019). The complex includes C. coelogynes, C. dracaenophilum, C. excelsum-altitudinum, C. tropicicola and C. yunnanense. A further strain, $C$. tongrenense was identified to the $C$. dracaenophilum species complex in the study, based on the multilocus phylogeny and morphological features. Amongst them, C. excelsum-altitudinum was described from healthy leaves of Bletilla ochracea (Orchidaceae) in Guizhou, China (Tao et al. 2013.), C. tropicicola were described from leaves of Citrus maxima and Paphiopedilum sp. in Thailand and a further strain from $C$. sp. in Mexico (Noireung et al. 2012, Damm et al. 2019). The C. coelogynes strain CBS 132504 is an endophytic Colletotrichum isolate from both Dendrobium spp. in China (Yuan et al. 2009, Gao and Guo, unpublished data). C. yunnanense was described from healthy leaves of Buxus sp. in Yunnan, China (Liu et al. 2007).

Morphological features and genes sequence data are recognised as a basis for describing new species, but sometimes morphological features of Colletotrichum are not stable and may change under different growth conditions (Liu et al. 2014). DNA sequence comparison and multi-gene phylogenetic analyses can provide sufficient evidence to show distinct taxa (Jeewon and Hyde 2016). However, single gene data, including ITS, are usually insufficient for species identification in most of the Colletotrichum species complexes (Hyde et al. 2009). Multi-locus phylogenies are therefore necessary to describe Colletotrichum species (Jayawardena et al. 2016).

The composition of endophytic microorganisms may depend on the plant age, tissue, host type and time of isolation (Rosenblueth and Martinez-Romero 2006). The new species, Colletotrichum tongrenense lives in stems and $C$. jishouense lives in roots and stems of Nothapodytes pittosporoides. Nothing is known about their infection strategies on the host. It is also the first report of Colletotrichum species from $N$. pittosporoides. This study enriches the host diversity of Colletotrichum.

\section{Acknowledgements}

This work was funded by grants of the National Natural Science Foundation of China (NSFC Grants nos. $31670027 \& 31460011$ \& 30870009). Sixuan Zhou thanks Dr. Shaun Pennycook, Prof. Jiangming Lv, Yongzhong Lu and Jianfei Gao for their help. 


\section{References}

Bhalkar BN, Patil SM, Govindwar SP (2016) Camptothecine production by mixed fermentation of two endophytic fungi from Nothapodytes nimmoniana. Fungal Biology120: 873883. https://doi.org/10.1016/j.funbio.2016.04.003

Baroncelli R, Talhinhas P, Pensec F, Sukno SA, Floch GL, Thon MR (2017) The Colletotrichum acutatum species complex as a model system to study evolution and host specialization in plant pathogens. Frontiers in Microbiology 8: 2001. https://doi.org/10.3389/ fmicb.2017.02001

Carbone I, Kohn LM (1999) A method for designing primer sets for speciation studies in filamentous ascomycetes. Mycologia 91: 553-556. https://doi.org/10.2307/3761358

Corda ACI (1831) Die Pilze Deutschlands. In: Sturm J (Ed.) Deutschlands Flora in Abbildungen nach der Natur mit Beschreibungen. Sturm, Nürnberg 3 (12): 33-64.

Damm U, Sato T, Alizadeh A, Groenewald JZ, Crous PW (2019) The Colletotrichum dracaenophilum, C. magnum and C. orchidearum species complexes. Studies in Mycology 92(5): 1-46. https://doi.org/10.1016/j.simyco.2018.04.001

Demain AL, Vaishnav P (2011) Natural products for cancer chemotherapy. Microbial Biotechnology 4(6): 687-699. https://doi.org/10.1111/j.1751-7915.2010.00221.x

Douanla-meli C, Unger JG (2017) Phylogenetic study of the Colletotrichum species on imported citrus fruits uncovers a low diversity and a new species in the Colletotrichum gigasporum complex. Fungal Biology 121(10): 858-868. https://doi.org/10.1016/j.funbio.2017.06.003

Fang WP (1981) Flora Republicae. Popularis Sinicae 46. Science Press, Beijing, Tomus, 49 pp.

Gardes M, Bruns TD (1993) ITS primers with enhanced specificity for basidiomycetes - application to the identification of mycorrhizae and rusts. Molecular Ecology 2: 113-118. https://doi.org/10.1111/j.1365-294X.1993.tb00005.x

Glass NL, Donaldson GC (1995) Development of primer sets designed for use with the PCR to amplify conserved genes from filamentous ascomycetes. Applied Environmental Microbiology 61: 1323-1330.

Glezpeńa D, Gómezblanco D, Reboirojato M, Fdezriverola F, Posada D (2010) ALTER: program-oriented conversion of DNA and protein alignments. Nucleic Acids Research 38: 14-18. https://doi.org/10.1093/nar/gkq321

Guerber JC, Liu B, Correll JC, Johnston PR (2003) Characterization of diversity in Colletotrichum acutatum sensu lato by sequence analysis of two gene introns, mtDNA and intron RFLPs, and mating compatibility. Mycologia 95(5): 872-895. https://doi.org/10.1080/1 5572536.2004 .11833047

Guo DY, Ling TJ, Cai XH (2015) Chemical constituents of Nothapodytes pittosporoides (Icacinaceae). Biochemical Systematics and Ecology 61: 293-296. https://doi.org/10.1016/j. bse.2015.06.039

Hall TA (1999) BioEdit: a user-friendly biological sequence alignment editor and analysis program for Windows 95/98/NT. Nucleic Acids Symposium Series 41: 95-98.

Hyde KD, Cai L, Cannon PF, Crouch JA, Crous PW, Damm U, Goodwin PH, Chen H, Johnston PR, Jones EBG, Liu ZY, McKenzie EHC, Moriwaki J, Noireung P, Pennycook SR, Pfenning LH, Prihastuti H, Sato T, Shivas RG, Tan YP, Taylor PWJ, Weir BS, Yang YL, Zhang JZ (2009) Colletotrichum names in current use. Fungal Diversity 39: 147-182. 
Hyde KD, Nilsson RH, Alias SA, Ariyawansa HA, Blair JE, Cai L, de Cock AWAM, Dissanayake AJ, Glockling SL, Goonasekara ID, Gorczak M, Hahn M, Jayawardena RS, van Kan JAL, Laurence MH, Lévesque CA, Li XH, Liu JK, Maharachchikumbura SSN, Manamgoda DS, Martin FN, McKenzie EHC, McTaggart AR, Mortimer PE, Nair PVR, Pawłowska J, Rintoul TL, Shivas RG, Spies CFJ, Summerell BA, Taylor PWJ, Terhem RB, Udayanga D, Vaghefi N, Walther G, Wilk M, Wrzosek M, Xu JC, Yan JY, Zhou N (2014) One stop shop: backbones trees for important phytopathogenic genera: I. Fungal Diversity 67: 21-125. https://doi.org/10.1007/s13225-014-0298-1

Index Fungorum (2017) http://www.indexfungorum.org/names/Names.asp

Jayawardena RS, Camporesi E, Elgorban AM, Bahkali AH, Yan J, Hyde KD (2017) A new species of Colletotrichum from Sonchus sp. in Italy. Phytotaxa 314(1): 55-63. https://doi.org/10.11646/phytotaxa.314.1.3

Jayawardena RS, Hyde KD, Damm U, Cai L, Liu M, Li XH, Zhang W, Zhao WS, Yan JY (2016) Notes on currently accepted species of Colletotrichum. Mycosphere 7: 1192-1260. https://doi.org/10.5943/mycosphere/si/2c/9

Jeewon R, Hyde KD (2016) Establishing species boundaries and new taxa among fungi: recommendations to resolve taxonomic ambiguities. Mycosphere 7(11): 1669-1677. https://doi.org/10.5943/mycosphere/7/11/4

Kusari S, Lamshöft M, Zühlke S, Spiteller M (2008) An endophytic fungus from Hypericum perforatum that produces hypericin. Journal of Natural Products 71:159-16. https://doi.org/10.1021/np070669k

Katoh K, Standley DM (2013) MAFFT multiple sequence alignment software version 7: improvements in performance and usability. Molecular Biology and Evolution 30(4): 772 780. https://doi.org/10.1093/molbev/mst010

Liu F, Cai L, Crous PW, Damm U (2014) The Colletotrichum gigasporum species complex. Persoonia 33: 83-97. https://doi.org/10.3767/003158514X684447

Liu X, Xie X, Duan J (2007) Colletotrichum yunnanense sp. nov., a new endophytic species from Buxus sp. Mycotaxon 100: 137-144.

Miller MA, Pfeiffer W, Schwartz T (2010) Creating the CIPRES Science Gateway for inference of large phylogenetic trees. 2010 Gateway Computing Environments Workshop (GCE), IEEE, 2010. https://doi.org/10.1109/GCE.2010.5676129

Noireung P, Phoulivong S, Liu F, Cai L, McKenzie EHC, Chukeatirote E, Jones EBG, Bahkali AH, Hyde KD (2012) Novel species of Colletotrichum revealed by morphology and molecular analysis. Cryptogamie, Mycologie, 33(3):347-362. https://doi.org/10.7872/crym. v33.iss3.2012.347

Nylander JAA (2004) MrModeltest v2. Program distributed by the author. Evolutionary Biology Centre, Uppsala University, Uppsala.

Qiao LJ, Zhou SX, Wen TC, Kang JC, Lei BX (2018) Diversity of endophytic fungi from Nothapodytes pittosporoides in Guizhou Province. Mycosystema 37(1): 43-51.

Rambaut A (2012) FigTree version 1.4. http://tree.bio.ed.ac.uk/software/figtree

Ronquist F, Teslenko M, van der Mark P, Ayres DL, Darling A, Höhna S, Larget B, Liu L, Suchard MA, Huelsenbeck JP (2012) MrBayes3.2: efficient Bayesian phylogenetic inference and model choice across a large model space. Systematic Biology 61(3): 539-542. https://doi.org/10.1093/sysbio/sys029 
Rosenblueth M, Martinez-Romero E (2006) Bacterial endophytes and their interactions with hosts. Acta Pharmacologica Sinica 19: 827-837. https://doi.org/10.1094/MPMI-19-0827

Silva MD, Cruz ES, Veloso TGR, Miranda L, Pereiram OL, Bocayuva MF, Kasuya MCM (2018) Colletorichum serranegrense sp. nov., a new endophytic species from the roots of the endangered Brazilian epiphytic orchid Cattleya jongheana. Phytotaxa 351(2): 163-170. https://doi.org/10.11646/phytotaxa.351.2.4

Stamatakis A (2014) RAxML version 8: a tool for phylogenetic analysis and post-analysis of large phylogenies. Bioinformatics 30(9): 1312-1313. https://doi.org/10.1093/bioinformatics/btu033

Stierle A, Strobel G, Stierle D (1993) Taxol and taxane production by Taxomyces andreanae, an endophytic fungus of Pacific yew. Science 260: 214-216. https://doi.org/10.1126/science. 8097061

Stierle A, Strobel G, Stierle D, Grothaus P, Bignami G (1995) The search forataxol-producing microorganism among the endophytic fungi of the Pacific yew, Taxus brevifolia. Journal of Nature Products 58: 1315-1324. https://doi.org/10.1021/np50123a002

Tao G, Liu ZY, Liu F, Gao YH, Cai L (2013) Endophytic Colletotrichum species from Bletilla ochracea (Orchidaceae), with descriptions of seven new species. Fungal Diversity 61(1): 139-164. https://doi.org/10.1007/s13225-013-0254-5

Than PP, Prihastuti H, Phoulivong S, Taylor PWJ, Hyde KD (2008) Chilli anthracnose disease caused by Colletotrichum species. Journal of Zhejiang University-Science B 9: 764-788. https://doi.org/10.1631/jzus.B0860007

Tibpromma S, Hyde KD, Bhat JD, Mortimer PE, Xu JC, Promputtha I, Doilom M, Yang JB, Tang AMC, Karunarathna SC (2018) Identification of endophytic fungi from leaves of Pandanaceae based on their morphotypes and DNA sequence data from southern Thailand. Mycokeys 33: 25-67. https://doi.org/10.3897/mycokeys.33.23670

Uzma F, Mohan CD, Hashem A, Konappa NM, Rangappa S, Kamath PV, Singh BP, Mudili V, Gupta VK, Siddaiah CN (2018) Endophytic fungi-alternative sources of cytotoxic compounds: a review. Frontiers in Pharmacology, 9: 309. https://doi.org/10.3389/fphar.2018.00309

Vaidya G, Lohman DJ, Meier R (2011) SequenceMatrix: concatenation software for the fast assembly of multi-gene datasets with character set and codon information. Cladistics 27: 171-180. https://doi.org/10.1111/j.1096-0031.2010.00329.x

White TJ, Bruns T, Lee S, Taylor JW (1990) Amplification and direct sequencing of fungal ribosomal RNA genes for phylogenetics. PCR protocols: a guide to methods and applications. Academic Press, San Diego,California 18: 315-322. https://doi.org/10.1016/B9780-12-372180-8.50042-1

Wijayawardene NN, Hyde KD, Lumbsch T, Liu JK, Maharachchikumbura SSN, Ekanayaka AH, Tian Q, Phookamsak R (2018) Outline of Ascomycota - 2017. Fungal Diversity 88: 167-263. https://doi.org/10.1007/s13225-018-0394-8

Wijayawardene NN, Hyde KD, Rajeshkumar KC, Hawksworth DL, Madrid H, Kirk PM, Braun U (2017) Notes for genera: ascomycota. Fungal Diversity 86(1): 1-594. https://doi.org/10.1007/s13225-017-0386-0

Wijayawardene DNN, Song Y, Bhat DJ, McKenzie EHC, Chukeatirote E, Wang Y, Hyde KD (2013) Wojnowicia viburni sp. nov. from China and its phylogenetic placement. Sydowia 65: 181-190. 
Yang YL, Liu ZY, Cai L, Hyde KD, Yu ZN, McKenzie EHC (2009) Colletotrichum anthracnose of Amaryllidaceae. Fungal Diversity 39: 123-146.

Yuan ZL, Chen YC, Yang Y (2009) Diverse non-mycorrhizal fungal endophytes inhabiting an epiphytic, medicinal orchid (Dendrobium nobile): estimation and characterization. World Journal of Microbiology \& Biotechnology 25(2): 295-303. hhttps://doi.org/10.1007/ s11274-008-9893-1

Zhou SX, Qiao LJ, Kang JC, Hyde KD, Ma XY (2017) A new species of Monilochaetes from Nothapodytes pittosporoides. Phytotaxa 326(2): 129-136. https://doi.org/10.11646/phytotaxa.326.2.4 